\title{
SOME EPIPHYTIC ALGAE IN THE VICINITY OF THE SETO MARINE BIOLOGICAL LABORATORY, WAKAYAMA PREFECTURE, JAPAN I
}

$\operatorname{AUTHOR}(\mathrm{S}):$

Cordero, Paciente A.

CITATION:

Cordero, Paciente A.. SOME EPIPHYTIC ALGAE IN THE VICINITY OF THE SETO MARINE BIOLOGICAL LABORATORY, WAKAYAMA PREFECTURE, JAPAN I. PUBLICATIONS OF THE SETO MARINE BIOLOGICAL LABORATORY 1975, 22(1-4): 121-145

ISSUE DATE:

1975-07-31

URL:

http://hdl.handle.net/2433/175885

RIGHT: 


\title{
SOME EPIPHYTIC ALGAE IN THE VICINITY OF THE SETO MARINE BIOLOGIGAL LABORATORY, WAKAYAMA PREFEGTURE, JAPAN $\mathbf{I}^{\text {' }}$
}

\author{
Paciente A. CORDERO, JR. ${ }^{2}$ \\ Seto Marine Biological Laboratory \\ With Text-figures $1-36$ and 2 Maps
}

Much has been written on the fauna, oceanography, submarine geology and foraminiferal assemblages in the vicinity of the Seto Marine Biological Laboratory (herein referred as SMBL), but relatively little is known of its marine flora.

Shirahama, site of the SMBL, is a coastal town of Wakayama Prefecture. It is fringed with boulders, rocks, sand and dotted with numerous rock-formed islets. Nevertheless, this has remained one of the more neglected biotopes of Japan, algologically. Early published literature on the marine algae of the area had been merely sporadic citations. This is exemplified by the works of Komai, Akatsuka and Ikari (1927) and later on Komai and Ikari (1929) which listed a total of 99 species: 1 blue-green, 21 green, 42 brown and 35 red algae, devoid of any taxonomic notes.

It was Okamura (1907-1935) who made the initial taxonomic study of some specimens from the area which he included in his monumental book entitled "Icones of Japanese Algae". He (1934), likewise, reported about 190 species of marine algae from Namariyama (or Kanayama, an old name of the Yuzaki district of Shirahama). Also, in the same year he described one new form of Gelidium pusillum (Stackh.) Le Jolis f. foliaceum Okamura, gathered from Shisojima. Two years later, Tanaka (1936) mentioned one species of Galaxaura, Gal. kjellmanii Weber van Bosse, its locality labeled simply as Seto, Kii Province.

In three separate papers, Umezaki $(1967,1968,1971)$ reported on the morphology of three red algae, namely, Dudresnaya japonica Okamura, Nemalion pulvinatum Grunow and Scinaia japonica Setchell, respectively. Another morphological work on Family Ulvaceae and Monostromaceae was published by Yoshida (1970, parts I and II) based on specimens from the area.

In a more recent paper, Yamamoto (1963) listed 206 species of marine algae from the coast of Wakayama Prefecture, some of which were gathered from Shirahama. In a precursory report on the algal flora in the vicinity of the SMBL, Cordero (1973)

1) Contributions from the Seto Marine Biological Laboratory, No. 598.

2) Office Address: Philippine National Herbarium, National Museum of the Philippines, Rizal Park, Manila, PHILIPPINES.

Publ. Seto Mar. Biol. Lab., XXII (1/4), 121-145, 1975. (Article 8) 
recognizes about 60 species of macroscopic algae. Of these, the rhodophytes count among the more dominant group followed by chlorophytes, phaeophytes, and cyanophytes, in the order of their abundance.

So far, there are no available reports on the epiphytic algal composition of the area, though Kita and Harada (1962) made the closest attempt having studied quantitatively some algae found on Zostera, a marine phanerogam.

\section{Description of the Area Studied}

The Prefecture of Wakayama has the most extensive shoreline among the memberprefectures of the Kii Peninsula. The site of the SMBL is the coastal part of Shirahama protruding seawardly facing the Pacific Ocean.

The present study covers the Seto portion (Map 1) of Tanabe Bay, from Engetsu islet (Station I), encircling the cape then moving inland ward up to the islet of Hatakejima (Station XII). So far, part one of this study concerns the area from Engetsu islet up to Toshima (Station VII), a total of seven collecting stations. The sea water is considerably clearer in the exposed portions (Stations II, III, VI, and VII) than in

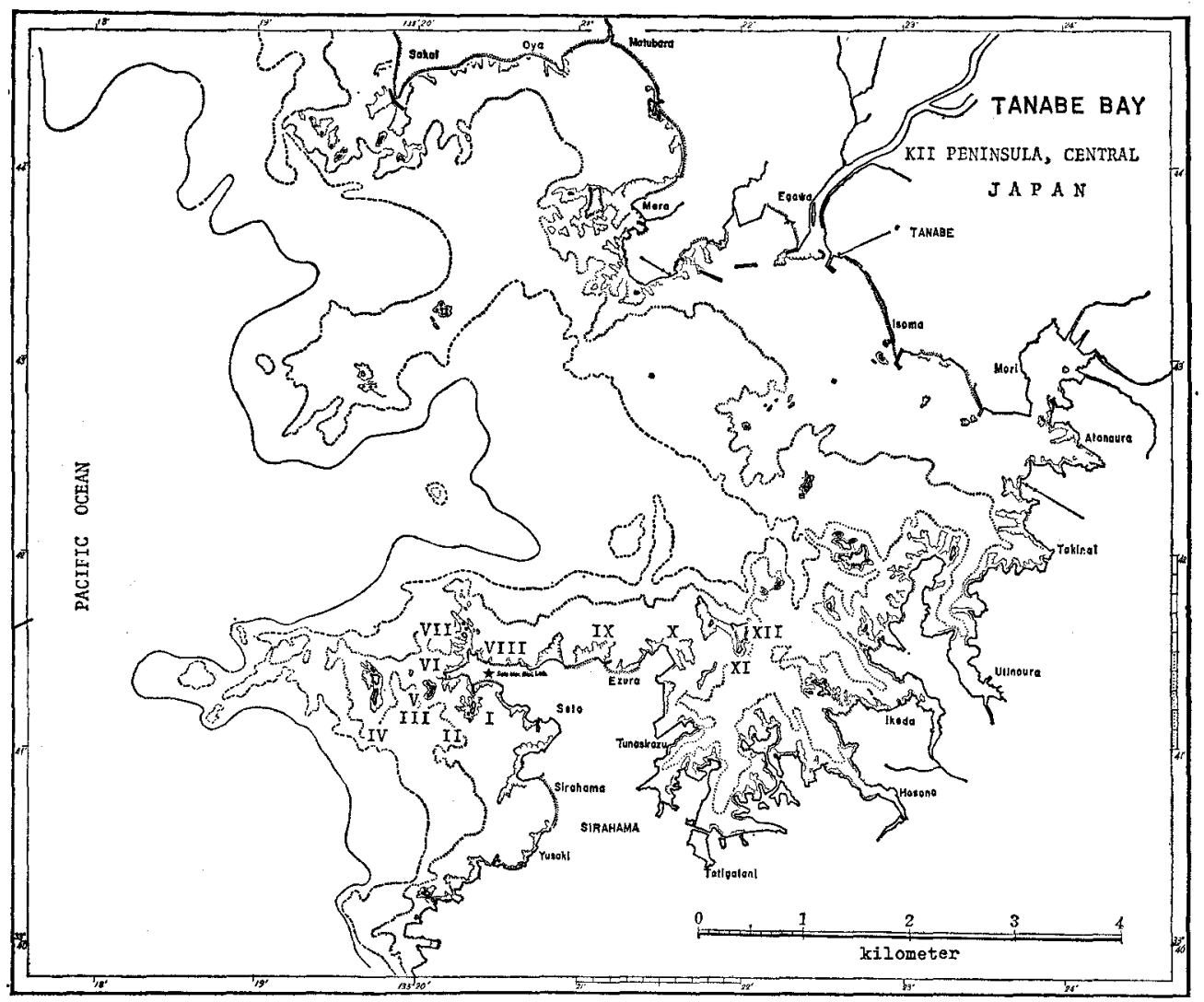

Map 1. Showing Tanabe Bay, with the collecting stations I to XII. 
the protected ones (Stations I, V, and VIII).

An interesting hydrographical feature is the north-eastward flow of the Kuroshio warm current off the southern tip of the Kii Peninsula. The path of this current plays an important role in the distribution and composition of both marine flora and fauna. The water becomes remarkably rough from late autumn till early spring brought about by the north-west monsoon. The mean high water level is $0.6 \mathrm{~m}$ and the highest is $1.2 \mathrm{~m}$ above, while the mean low water level is $0.5 \mathrm{~m}$ and the lowest is $1.3 \mathrm{~m}$ below the mean sea level (Mii, 1962). The average water temperature is $19.85^{\circ} \mathrm{C}$, and the range is generally from $13^{\circ}$ to $28^{\circ} \mathrm{C}$.

The collecting stations of the area show some varied characteristics (Map 2).

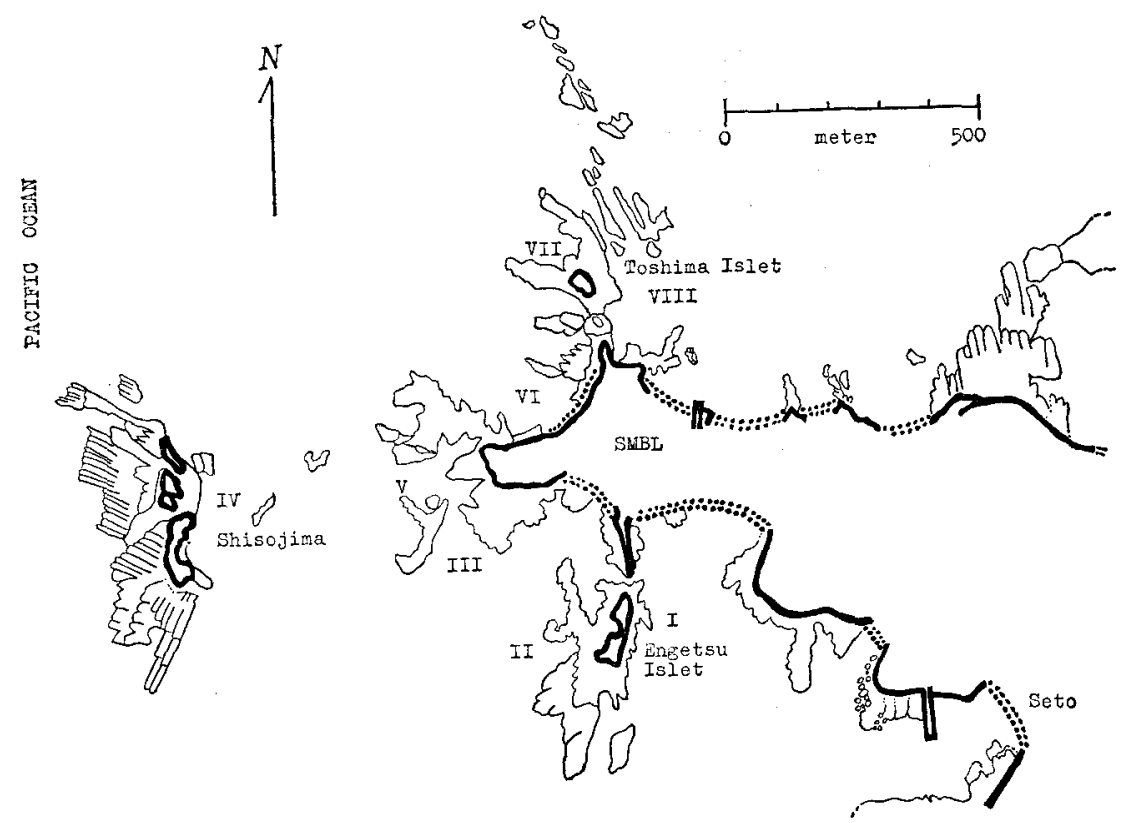

Map 2. Showing the detailed topography of the collecting stations I to VIII. SMBL means the site of the Seto Marine Biological Laboratory.

Station I, protected, includes a sandy-rocky beach of Kanayama Bay, 'harbor' and the front side of Engetsu islet. Station II, opposite side of the islet, is subjected to wave action every now and then. Station III is an indented portion consisting of a narrow sandy beach where several freshwater seepages empty into it. Westward is a flatlying rocky shore extending a few meters sea ward with numerous tidal pools. Across this is a rock formation very much violent and with no defined shoreline. Farther northward is Station V, also a rock formation that is submerged during extreme high tide. Partly covered by a rock-formed islet is Station VI, which also protects an indented sandy-rocky extension of the cape. Station VII, Toshima islet, appears like a pointed extension with only a very narrow rocky coast that drops off 
abruptly. This is a surf-beaten habitat covered with shells, barnacles and mussels near the splash zone. On the opposite side is Station VIII. Like Station I, this area is protected from waves and strong wind. There is, but, relatively lesser water agitation in this station.

The substratum below 7 to 10 meters is predominantly rocky to sandy-gravelly. It becomes silty-clayish infratidally.

\section{Materials and Methods}

This study deals with the epiphytic algae, other than diatoms, in the vicinity of the SMBL, containing a total of 25 species. Thus,

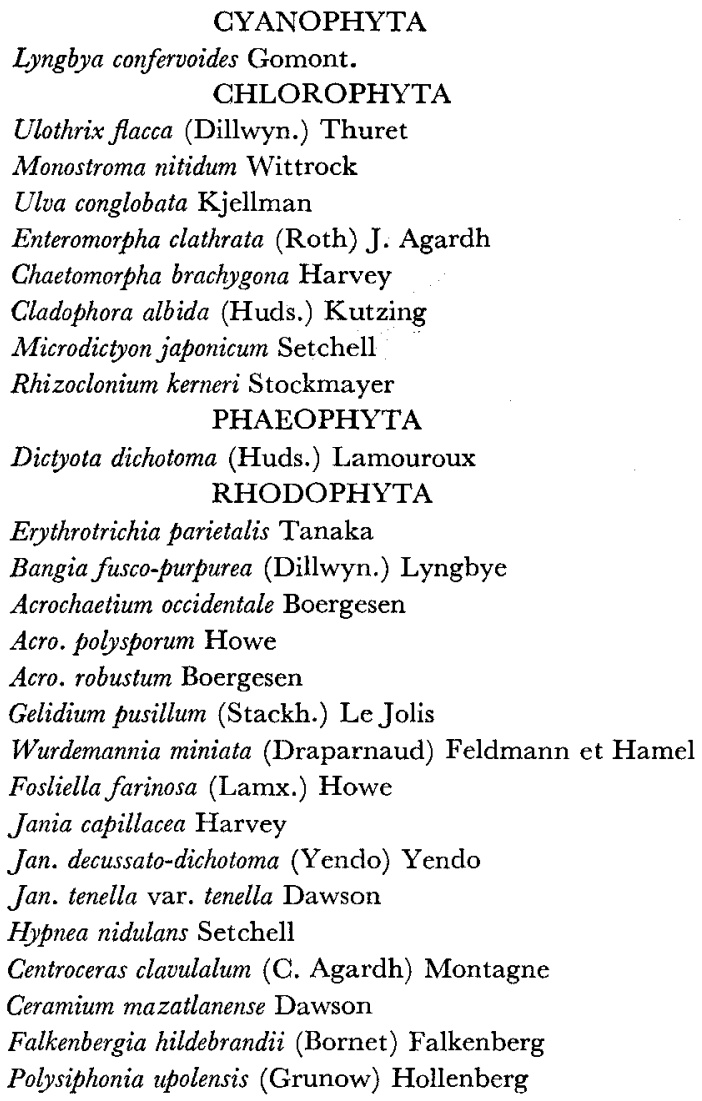

These plants were found attached to the coarser algae gathered during the winter months of 1973. The host plants were collected from various habitats, e.g. exposed and covered areas, tide pools, otherwise mostly saxicolous. A large proportion of the hosts are found intertidally. The larger infratidal species are easily gathered either by skin- or SCUBA-diving. The principal hosts observed were usually mature, large and coarse species, such as Galaxaura, Laurencia, Pterocladia, Cryptonemia, Sargassum, Enteromorpha and few calcareous ones. 
As foreseen, the facilities of the SMBL will doubtless be used by future investigators, many of them interested in organisms depending directly upon the algae for food, attachment or protection. As such, it became the added task of this writer to make the present account as useful as possible. Thus, some of the more important features of each species were drawn from actual specimens and artificial keys to the genera and species provided as taxonomic guides.

Following the citations of the original description, mostly, is a brief description of each species, its habitat, local distribution, type locality as well as date of collection.

To further guide future workers, the author provided each species with his own field numbers, series of 1973, Wakayama, Japan. These numbers will enable a worker to determine the plant that this author had in mind. The specimens, host and epiphyte, are kept in the laboratory room of the author, also at the SMBL. The host plants are dried on herbarium sheets while epiphytic ones are permanently mounted on glycerine micro-slides.

\section{Observations}

Our findings show that some plants contained in this report are either new or noteworthy to Japan and/or Shirahama. Out of the 25 species listed above, six are believed to be new to Japan. These are, Acrochaetium occidentale, Acro. polysporum, Acro. robustum, Jania tenella var. tenella, Falkenbergia hildebrandii, and Polysiphonia upolensis. While the following species are newly recorded in the vicinity of the SMBL: Ulothrix flacca, Chaetomorpha brachygona, Rhizoclonium kerneri, Erythrotrichia parietalis, Acrochaetium occidentale, Acro. polysporum, Acro. robustum, Wurdemannia miniata, Fosliella farinosa, Jania capillacea, Jan. decussato-dichotoma, Jan. tenella var. tenella, Ceramium mazatlanense, Falkenbergia hildebrandii, and Polysiphonia upolensis.

Some of the materials herein cited were previously listed by Komai et al. (1927), but without any descriptions, like Dictyota dichotoma and Bangia fusco-purpurea (as B. atropurpurea gamma fusco-purpurea). Likewise, reported by Yamamoto (1963), though devoid of taxonomic notes, are Monostroma nitidum, Cladophora albida, Dictyota dichotoma, Bangia fusco-purpurea, and Hypnea nidulans. These undescribed species are therefore good as 'unknown' to Shirahama.

In Japan only a few biologists have been attracted to study algal epiphytes. This explains the want of reports in the literature available. Some of the more prominent Japanese workers who have made partial studies on this lowly plants are Okamura, Yendo, Yamada, Kawashima, Tokida, Inaba, Noda, etc. The works of Tanaka $(1963,1968)$, Tanaka and Itono $(1968,1969,1972)$ based on the flora of Southern Japan as well as those of Noda and Nakamura representing the Japan Sea and Northern Japan should merit special mention.

Further studies on the algal epiphytes found in other places of Japan show that those reported by Tanaka and Itono compare favorably with ours. Such that thirteen species present in this report were reported from the subtropical and tropical waters of Kagoshima and its neighboring islands, including Yonakuni at the extreme 
southern end of Okinawa. The specimens that are common to Shirahama and Kagoshima (Amami Oshima down to Okinawa) are the following: Ulothrix flacca, Ulva conglobata, Monostroma nitidum, Microdictyon japonicum, Rhizoclonium kerneri, Dictyota dichotoma (also reported from the Japan Sea), Bangia fusco-purpurea, Jania capillacea, Jania decussato-dichotoma, Gelidium pusillum, Hypnea nidulans, Ceramium mazatlanense, and Centroceras clavulatum. This comparison is based on the works of Tanaka and Itono for the past decade.

Percentage-wise, the present findings suggest that algal epiphytes thrive best in the temperate region. There are no marked differences between the species considered common to the above habitats other than their gross-morphological set-up. Such difference may be influenced largely by factors like ecological variations and others.

\section{Taxonomic Treatment}

Specimens cited in this paper were collected by the author from the same localitySeto, Shirahama, Wakayama Prefecture, Japan. The specific area of collection is written opposite 'Local distribution.'

\section{GYANOPHYCEAE}

Lyngbya, G. Agardh

Lyngbya confervoides Gomont.

Figs. 1-2.

Harvey 1858: 103, pl. 47, figs. 1-3; Taylor 1928: 44, pl. 1, fig. 20; Umezaki 1952: 246; Dawson 1954: 380, fig. 3b, c; Tanaka 1956: 17; Buggeln and Tsuda 1966:9.

Plants forming fine entangled masses on rocks, coarser algae or other submerged objects. Silky filaments to $117-$ in diameter, unbranched; cells very thin, disc-like, shorter than long (4-6 times), constrictions on trichome absent; apical cells noncalyptrate, rotund.

The present report confirms an earlier record made by Umezaki from the same area. Its closest relative is Lyngbya majuscula, but differs from it by not having tapered trichome among others.

Materials examined: PAC-JW-1973-93, December 10, 1973.

Habitat: Plant found growing on Gal. fastigiata (PAC-JW-1973-24).

Local distribution: Engetsu islet, Station II, exposed.

Type locality: Cadiz, Spain.

\section{GHLOROPHYGEAE}

Key to the Genera:

1. Thallus unbranched, not tubular Ulothrix

Thallus branched, tubular Enteromorpha

2. Thallus structure of one cell layer Monostroma Thallus structure of two cell layers Ulva 
3. Plant filamentous, unbranched; cells as long as broad, to 2-4 diameter long basally Plant filamentous, rarely or always branched; cell dimensions not as above .. 4.

4. Plant body conspicuously long; not anastomosing Rhizoclonium

Plant body rather spread; anastomosing Microdictyon

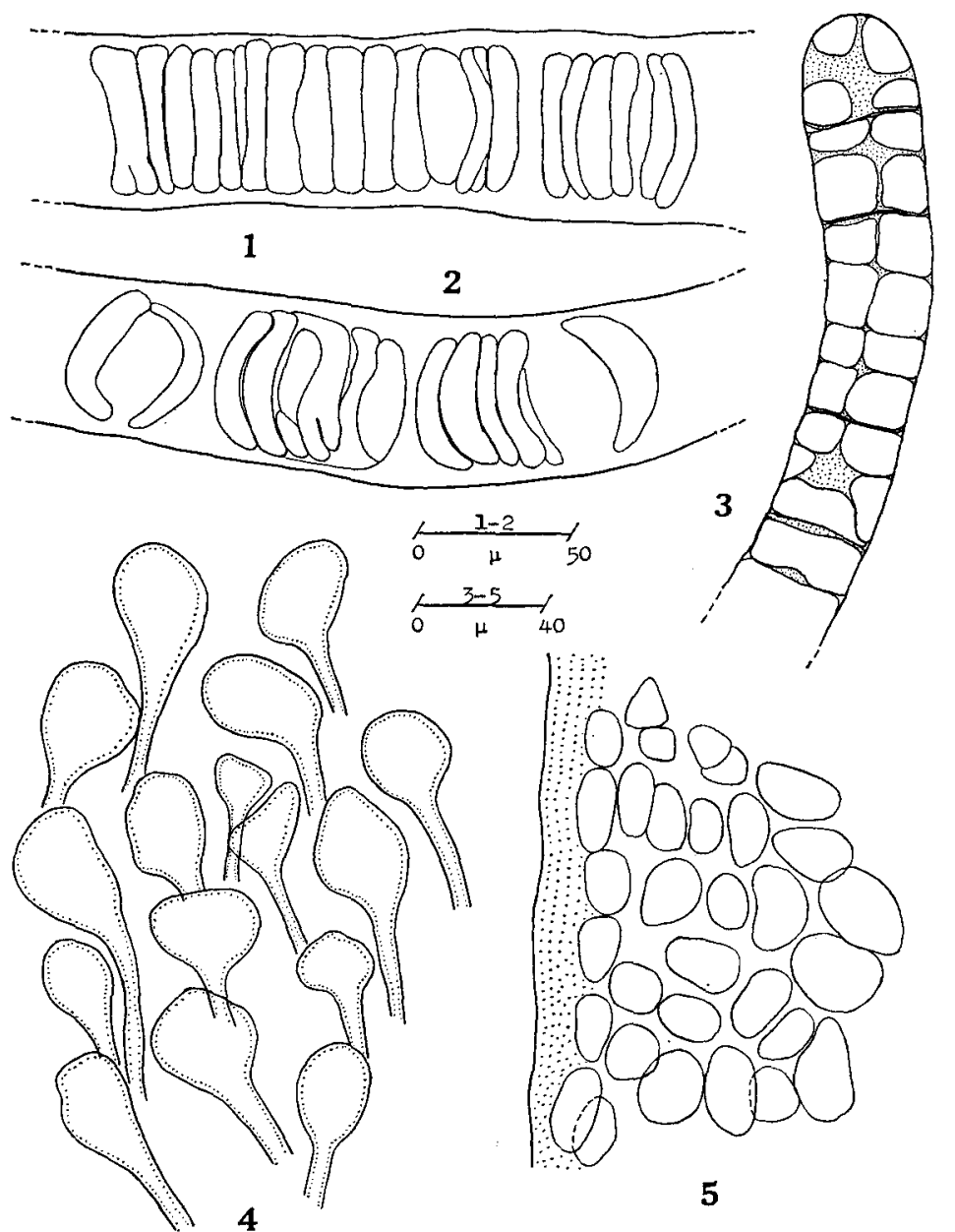

Figs. 1-2. Lyngbya confervoides (1, 2) Portion of filaments.

Fig. 3. Ulothrix flacca (3) Apical part of filament showing stellate chromatophore. Figs. 4-5. Monostroma nitidum (4) Surface section of cells. (5) Rhizoidal cells.

\section{Ulothrix, Kutzing}

Ulothrix flacca (Dillwyn.) Thuret.

Fig. 3.

Setchell and Gardner 1903: 217; Okamura 1936: 7, text-figs. 1-6: Segawa 1956: 2, pls. 1-2.

Plant filamentous to $16 \mu$ or more broad; unbranched; cells of one series, angular, $(-20 \mu)$ in diameter; chromatophore becoming stellate 'upon maturity'. 
This is one of the more commonly reported species from Japan as evidenced by the works of the authors above cited.

Materials examined: $\quad$ PAC-JW-1973-96, December 10, 1973.

Habitat: On Gal. fastigiata (PAC-JW-1973-24).

Local distribution: Engetsu islet, Station II, exposed.

Type locality: Unknown to this writer.

Monostroma (Thuret, 1854) Wittrock, 1866

Monostroma nitidum Wittrock.

Figs. 4-5.

Okamura 1936: 25, pl. 11; Okamura 1938: 34 .

Plants rather young, barely $5 \mathrm{~mm}$ tall, bright green, expanded to ovate; margin entire; basal attachment stupose, small; cells from mid to apical portions irregular, usually oval to angular with rounded angle, to $16 \mu$ in diameter; rhizoidal cells stipitate, ovate to $20 \mu$ in diameter.

Material examined: PAC-JW-1973-99, December 10, 1973.

Habitat: Collected on Laurencia (PAC-JW-1973-30).

Local distribution: Engetsu islet, Station II, exposed.

Type locality: Unknown to this writer.

\section{Ulva, Linnaeus}

Ulva conglobata Kjellman.

Okamura 1916-28: 58, pl. 165, figs. 1, 3-10; Okamura 1936: 9; Okamura 1934: 23.

Plant light green, becoming foliaceus, irregularly split upon maturity; margin ruffled; cells in surface view irregularly shaped, $(-15 \mu)$ broad.

Our observations favorably compare with those made by the above author based on Japanese materials. This is very common intertidally.

Materials examined: PAC-JW-1973-85, December 10, 1973.

Habitat: On Pterocladia (PAC-JW-1973-31).

Local distribution: Engetsu islet, Station II, exposed.

Type locality: Unknown to this writer.

\section{Enteromorpha, Link}

Enteromorpha clathrata (Roth) J. Agardh.

Figs. 6-7.

1883: 153; Yoshida 1970: 269.

Plants soft, young, bright green, attached, barely $0.5 \mathrm{~cm}$ in height, tubular, collapsed; branches several apically, similar to main blade, to $330 \mu$ broad; cells large to $18 \mu$ wide in surface section, rather regularly arranged, quadrate to subquadrate, angles plain.

Materials examined: PAG-JW-1973-87; PAC-JW-1973-104A1, and PAG- 
JW-1973-114, December 10, 14, 19, 1973, respectively.

Habitat: Materials collected on Pterocladia (PAC-JW-1973-31); Gal. subverticillata (PAC-JW-1973-62); and, Gal. papillata (PAC-JW-1973-79).

Local distribution: Engetsu islet, Station II, exposed; Oguso, Station VI, exposed; and, Toshima, Station VIII, protected.

Type locality: Baltic Sea.

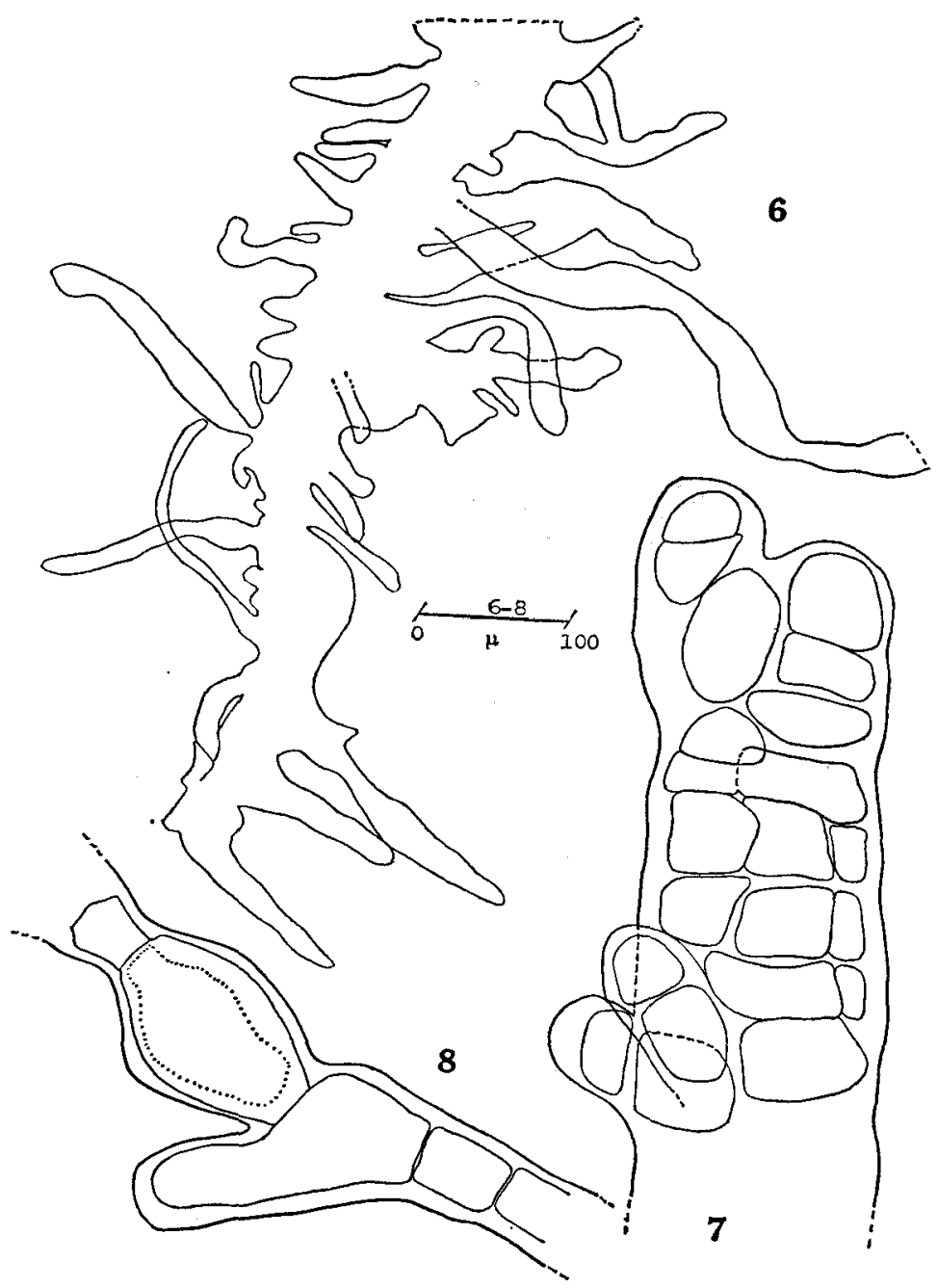

Figs. 6-7. Enteromorpha clathrata (6) Basal-mid portion of plant showing lateral proliferations. (7) Detailed drawing of matured filament.

Fig. 8. Cladophora albida (8) Portion of filament with bulbous cell.

\section{Chaetomorpha, Kutzing}

Chaetomorpha brachygona Harvey.

Figs. 9-10.

Boergesen 1913: 18; Taylor 1928: 60. 
Plants rather immature, loose-lying, unbranched; cells as long as broad above, to $75 \mu$ wide or more becoming 2-4 diameter long basally; sometimes inflated.

The Florida materials of Taylor (1928) appear identical with this Central Pacific Japanese plant.

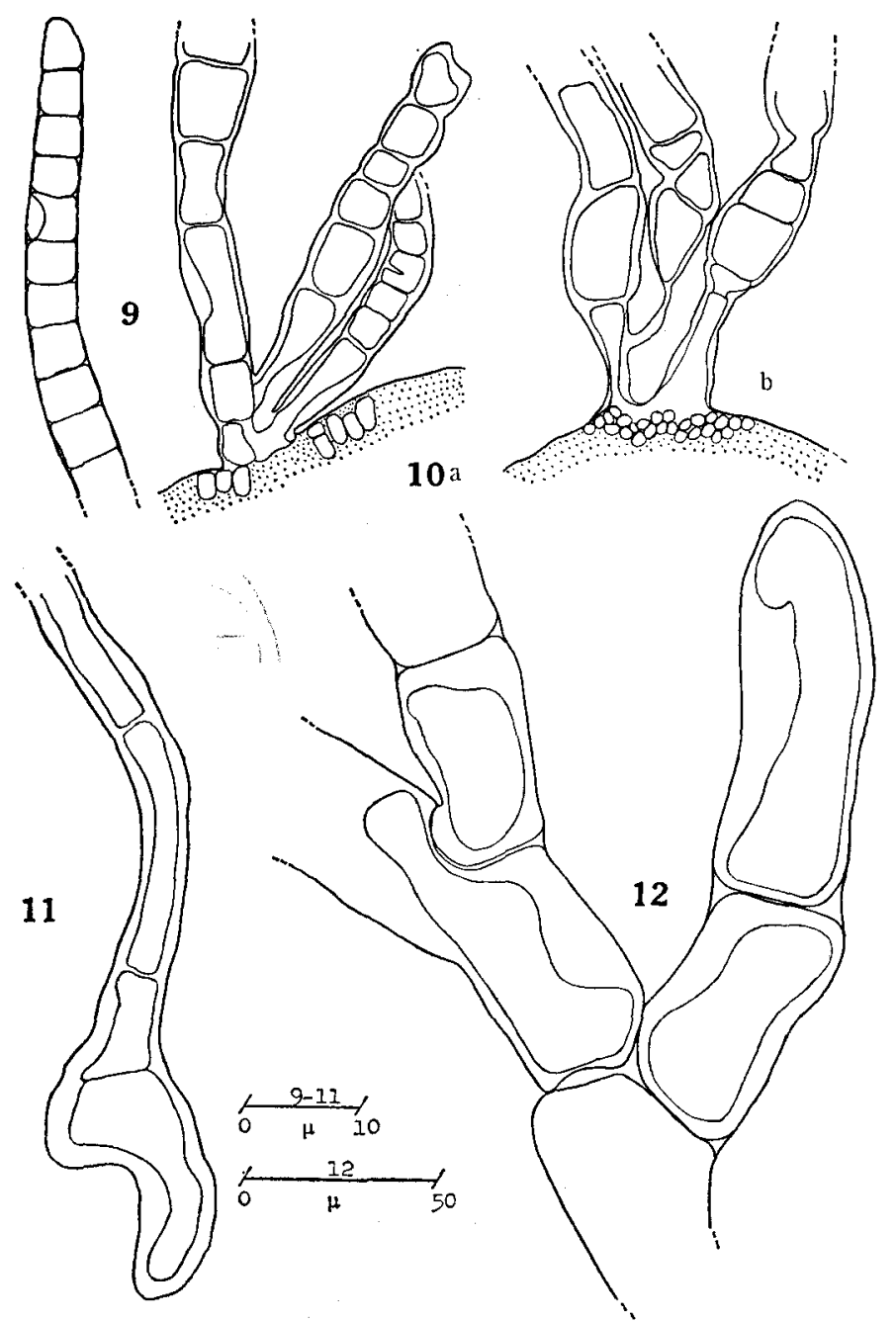

Figs. 9-10. Chaetomorpha brachygona (9) Tip of filament.

Fig. 11. Rhizoclonium kerneri (11) Basal portion of plant.

Fig. 12. Microdictyon japonicum (12) Portion of thallus showing 3 cells anastomosing.

Materials examined: PAC-JW-1973-90, December 10, 1973.

Habitat: Collected as epiphyte from another larger crustose epiphytic plant, Fosliella farinosa (PAC-JW-1973-88) growing on still another larger plant, Laurencia (PAG-JW-1973-30).

Local distribution: Engetsu islet, Station II, exposed. 
Type locality: Unknown to this writer.

\section{Gladophora, Kutzing}

Cladophora albida (Huds.) Kutzing, prox.

Fig. 8.

1843: 267; Kutzing Tab. Phyc. pl. 4, fig. b: Dawson 1954: 386, fig. 7, f, g.

Plants bright green, young, to $1.0 \mathrm{~cm}$ tall, slender, to $264 \mu$ in diameter; cells 2-6 diameter long; branching laterally, alternately.

Due to the nature of our materials, we entertain some doubts as to its specific assignment. However, filament measurements and other features are in accord with those previously reported from the south Pacific Ocean, viz., Dawson (1954) from Vietnam.

Materials examined: PAG-JW-1973-103, December 14, 1973.

Habitat: Epiphytic on Gal. subverticillata (PAC-JW-1973-62).

Local distribution: Oguso, Station VI, exposed.

Type locality: Great Britain.

\section{Microdictyon, Decaisne}

Microdictyon japonicum Setchell.

Figs. 12 and 14.

Egerod 1952: 363, pl. 32 b, figs. 5, 6b.

Plant forming mesh of indefinite extent, usually tangled among coarser algae. Thallus delicate, umbilicate blade 75 to $104 \mu$ in diameter, anastomosing; segments slightly tapered; rhizoids slender; branching generally to $2-4$ clusters per node.

At first referred to another Japanese species, Mic. okamurai, but the dimension of the mesh and blade and the more stellate main segment of the present materials guided us in naming them as Mic. japonicum. Our findings compare favorably with Egerod's account of her Hawaiian specimens.

To some extent this plant may not at all be considered epiphytic but plainly tangled upon macroscopic algae especially upon attaining maturity.

Materials examined: PAC-JW-1973-92 and PAC-JW-1973-98, December 10, 1973.

Habitat: Attached to Gal. fastigiata (PAC-JW-1973-24) and Laurencia (PACJW-1973-30).

Local distribution: Both specimens come from the same area, Engetsu islet, Station II, exposed.

Type locality: Japan.

\section{Rhizoclonium, Kutzing}

Rhizoclonium kerneri Stockmayer.

Fig. 11 .

Boergesen 1913: 20, fig. 8; Dawson 1954: 386, fig. 7 a-c. 
Thallus unbranched; basal cells showing constrictions though very slight, several times long as broad, 188 to $330 \mu$ broad, becoming slender apically; apex bluntish; rhizoid short, one to few-celled, simple.

Our plant agrees well with the same species described by Dawson from Vietnam, except for minor differences in cell dimensions.

Materials examined: PAG-JW-1973-106, December 14, 1973.

Habitat: Growing on another epiphyte, Ent. clathrata (PAC-JW-1973-104A1), one of the coarser epiphytes of Gal. subverticillata (PAC-JW-1973-62).

Local distribution: Oguso, Station VI, exposed.

Type locality: Not designated.

\section{PHAEOPHYGEAE}

Dictyota, Lamouroux

Dictyota dichotoma (Huds.) Lamouroux.

Taylor 1928: 119, pl. 16, fig. 14; Dawson 1950: 90.

Plant barely $10 \mathrm{~mm}$ in height; flattish; dichotomously regular; apices roundish.

A very widely distributed plant but usually reported from the warmer seas.

Materials examined: PAC-JW-1973-118, December 14, 1973.

Habitat: Growing on Gal. fastigiata (PAC-JW-1973-47)

Local distribution: Station III, exposed.

Type locality: England.

\section{RHODOPHYCEAE}

Key to the Genera:

1. Plant calcified

8.

Plant uncalcified

2

2. Gells enclosed in jelly-like substance .......................................... Acrochaetium

Cells enclosed sometimes in jelly-like substance, but but most of the time by other substances ... 3 .

3. Cross-section reveals cells arranged pericentrically, always $\mathbf{3}$ in number

Falkenbergia

Cross-section reveals cells not pericentrically arranged, if pericentric always more than 3

4. Thallus with no rhizoidal filaments

Polysiphonia

Thallus with slender rhizoidal filaments

Gelidium

5. Axes bearing numerous short branchlets equally distributed on all sides

Axes with few small branchlets unevenly distributed

Hypnea

6. Plant filaments always mono- to bisiphnonous Wurdemannia

Plant filaments mono- to polysiphonous

Erythrotrichia

7. Nodes bearing usually 2-celled siphonous growths; apex forcipate Bangia

Nodes without spinous processes; apices not as above

Centroceras

Thallus segmented, cylindric

Ceramium

Thallus non-segmented, crustose Jania Fosliella

\section{Erythrotrichia, Areschoug}

Erythrotrichia parietalis Tanaka.

Figs. 15-16. 
1952: 18, fig. 10 a-e; Dawson 1954: 411, fig. 23 d-e; Trono 1969: 42, for var. majuscula Tanaka et Pham Hoang Ho 1962: 33, fig. 9 f-h; for Eryth. polymorpha, Dawson 1964: 31, pl. 29, A-C.

Plants to $3 \mathrm{~mm}$ in height, caespitose; cells uniseriate, 1.0 to 1.5 times shorter than broad, rarely as tall as wide, ovate to quadri-angular with prominent rounded angles, $10 \mu$ or more broad; cell wall 'thickened'; basal cells to 4 diameters long; vegetative filament (PAC-JW-1973-87) expanding towards apex, to $16 \mu$ diameter; parietal chromatophore devoid of central pyrenoid; reproductive structures not seen.

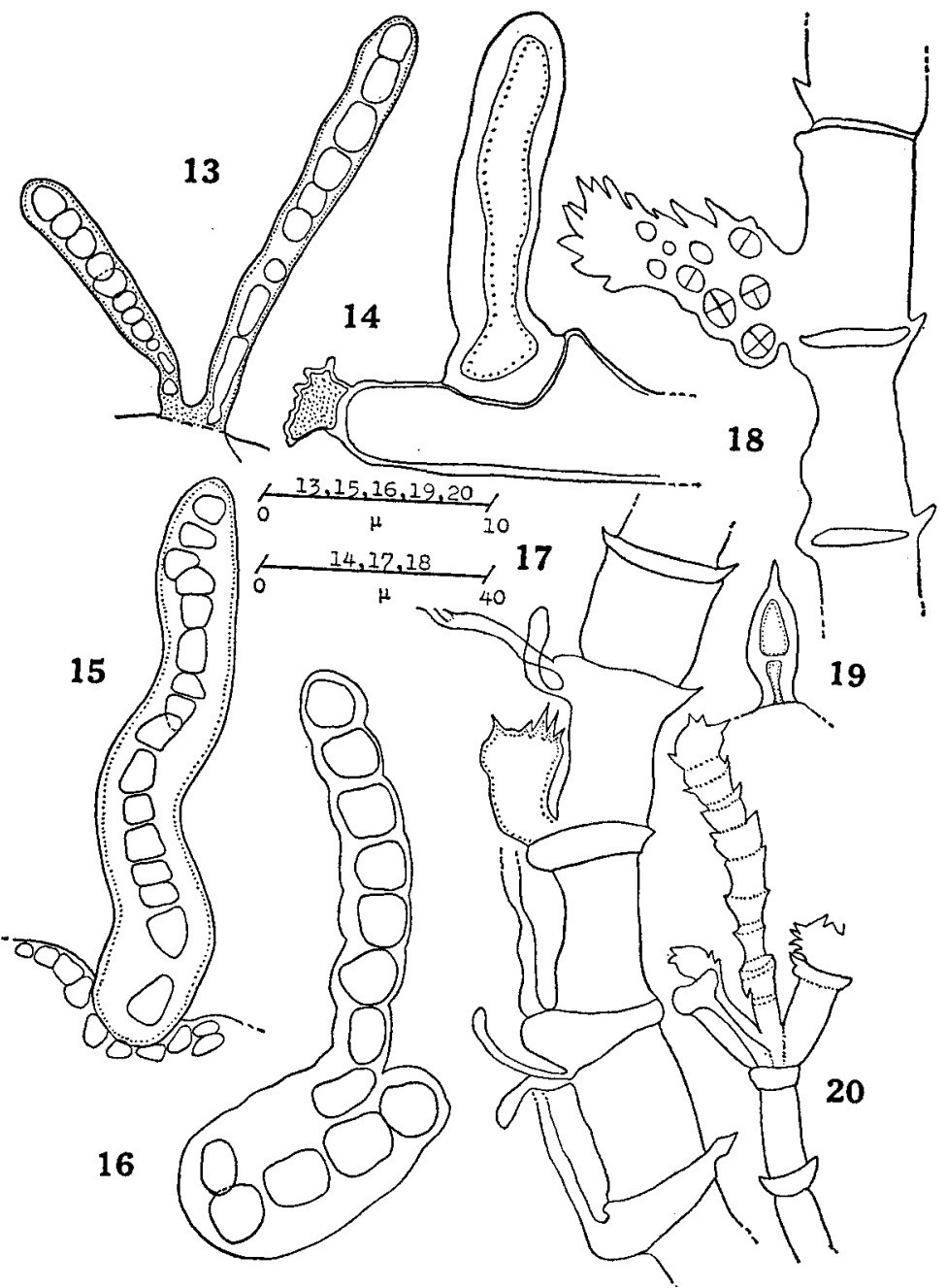

Fig. 13. Bangia fusco-purpurea (13) Habit of young plant.

Fig. 14. Microdictyon japonicum (14) Nature of hapteron.

Figs. 15-16. Erythrotrichia parietalis (15) Young plant. (16) Juvenile plant slightly constricted

Figs. 17-20. Centroceras clavulatum (17) Portion of thallus with 'bud'. (18) Tetrasporangial branch. (19) Two-celled spinous growth. (20) Apical portion showing mode of branching 
Our materials possess identical features originally observed by Tanaka (1952) based on the type specimen from Japan. Tanaka and Pham Hoang Ho's (1962) account of Eryth. parietalis var. majuscula is in a way comparable with ours. But (PAC-JW-1973-84) resembles Goniotrichium humphreyii as seen in Tanaka's (1952) paper! Some features of Dawson's (1964) plant from Peru, Eryth. polymorpha appear to duplicate those observed in the present materials.

There is no doubt that the genus is generally Pacific in distribution having been amply reported by several investigators.

Materials examined: PAC-JW-1973-91, PAC-JW-1973-87, PAC-JW-197384), December 10, 1973.

Habitat: Attached on matured Fosliella farinosa (PAC-JW-1973-88), also an epiphyte of Laurencia (PAC-JW-1973-30).

Local distribution: Engetsu islet, Stations I and II, protected and exposed habitats, respectively.

Type locality: Hyuga Province, Japan.

Bangia, Thuret

Bangia fusco-purpurea (Dillwyn.) Lyngbye.

Fig. 13.

Okamura 1936: 377, text-figs. 1-3; Tanaka 1952: 23, pl. II, 2.

Frond minute, erect, attached to substratum by rhizoids originating from the lower part of the filament; filaments of single row of cells; cells quadrate with rounded angles.

Materials examined: PAC-JW-1973-84A, December 10, 1973.

Habitat: On Fosliella farinosa (PAC-JW-1973-88).

Local distribution: Engetsu islet, Station II, exposed.

Type locality: Unknown to this writer.

\section{Acrochaetium, Naegeli}

Key to the Species:

1. Basal attachment made up of one cell Acro. robustum

Basal attachment of many cells Acro. polysporum

2. Monosporangia borne adaxially, singly, seriate, pedicellate (one-celled) Monosporangia borne laterally, sessile Acro. occidentale

1. Acrochaetium occidentale Boergesen.

Fig. 21.

1915: 44, figs. 42, 43; Dawson 1954: 414, fig. 25 d-e.

Plants forming reddish fur on Falk. hildebrandii; ( $-2 \mathrm{~mm})$ tall; filaments to $13 \mu$ in diameter; lateral branches alternate, apices blunt; cells 2 to 6 diameters long; monosporangia lateral, sessile, bluntish apically, obovoid or globose.

The materials at hand seem to agree very well with the those described by Boergesen (1915) and Dawson (1954).

Materials examined: PAC-JW-1973-107, December 14, 1973. 
Habitat: Epiphytic on Falk. hildebrandii (PAC-JW-1973-104), which was growing on Gal. subverticillata (PAC-JW-1973-62).

Local distribution: Oguso, Station VI, exposed.

Type locality: Virgin Islands.

2. Acrochaetium polysporum Howe.

Fig. 22.

Dawson 1964: 36, pl. 29, figs. E-F.

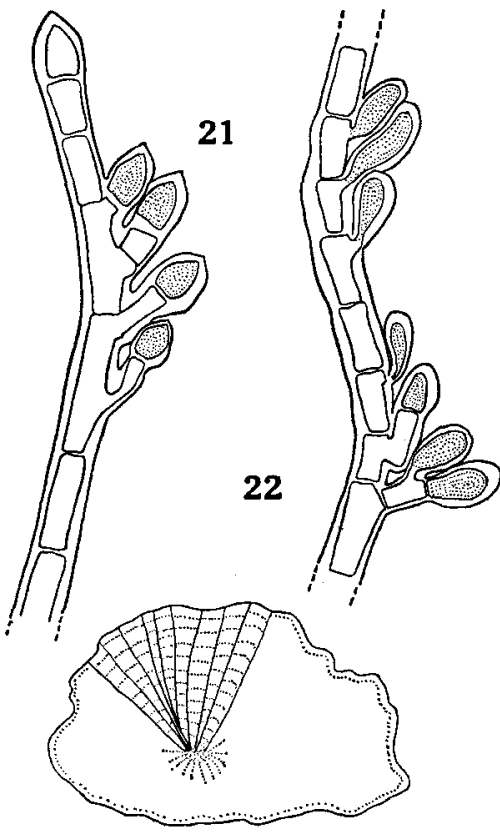

26
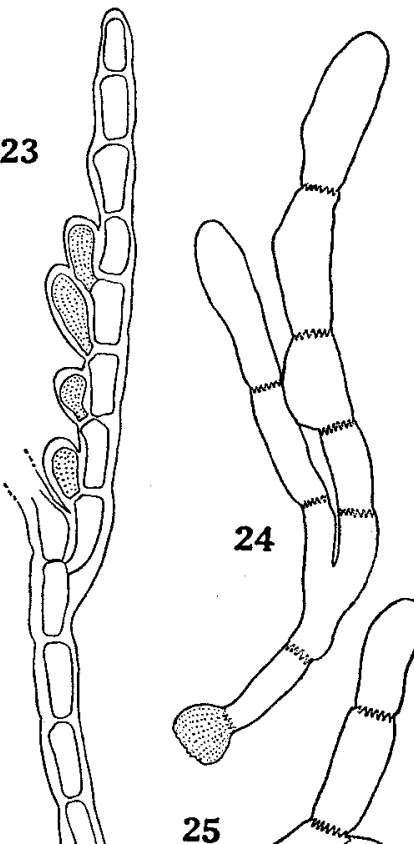

25

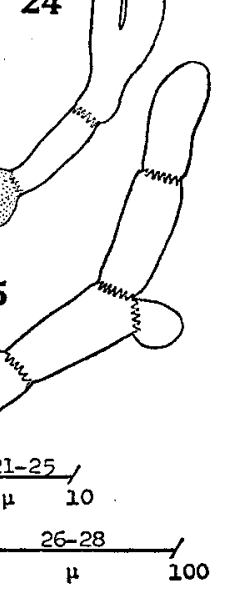

28

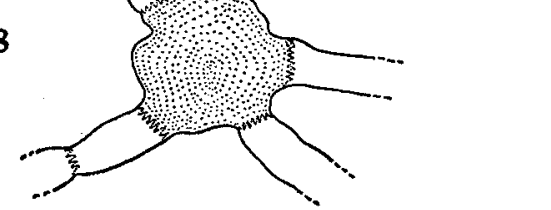

Fig. 21. Acrochaetium occidentale (21) Fertile branch bearing spores with prominent pointed apex.

Fig. 22. Acrochaetium polysporum (22) Pedicellate monosporangia paired and/or single.

Fig. 23. Acrochaetium robustum (23) Monosporangia borne seriately.

Figs. 24-25. Jania capillacea $(24,25)$ Habit of the plant.

Figs. 26-28. Fosliella farinosa (26) Diagrammatic drawing of the habit. (27) Cells in surface section. (28) Cells in section after decalcification. 
Plant tufted, to several millimeters tall; erect branches 7 to $10 \mu$ in diameter, filamentous; cells 2-3 diameters long (-4); branching basally; fertile branches bearing spores in short secund series, apices strongly attenuate; monospores borne adaxially, singly, seraite, attenuate, generally pedicellate (1-celled), obovoid, to $10 \mu$ in diameter.

Except for some minor variations, our materials compare favorably with Dawson's (1964) descriptions of his specimens from Peru.

Materials examined: PAC-JW-1973-105, December 14, 1973.

Habitat: Collected on margin of young Ent. clathrata (PAC-JW-1973-104A1), likewise, one of the many epiphytes borne by Gal. subverticillata (PAG-JW-1973-62).

Local distribution: Oguso, Station VI, exposed.

Type locality: Unknown to this writer.

3. Acrochaetium robustum Boergesen.

Fig. 23.

1915: 40, fig. 4 a-b; Abbott 1947: 203, fig. a-c; Trono 1969: 43, pl. 4, figs. 1-4.

Plants to $2 \mathrm{~mm}$ tall, anchored by means of branched basal cells; branching generally alternato-lateral; cells 2-3 diameters long filled with parietal chromatophore; monosporangia sessile or pedicellate, lateral, singly or in pairs, $13 \mu$ in diameter, ovate.

Our plants answer the type description of Boergesen (1915). This species is confirmed to be Pacific in distribution, Abbott (Hawaii) and Trono (Caroline Islands).

Materials examined: PAG-JW-1973-102, December 14, 1973.

Habitat: Attached on Jan. capillacea (PAC-JW-1973-101), another epiphyte growing on Gal. subverticillata (PAC-JW-1973-62).

Local distribution: Oguso, Station VI, exposed.

Type locality: Virgin Islands.

\section{Gelidium, Lamouroux}

Gelidium pusillum (Stackh.) Le Jolis.

Okamura 1901-12: 11, pl. 54, figs. 10-14; Okamura 1934: 50, pl. 17, figs. 1-2; pl. 34, figs. 1-2; Taylor 1928: 142, pl. 20, fig. 8; pl. 22, fig. 7; pl. 23, fig. 3; Dawson 1954: 420, fig. 31 a-c; Dawson 1944: 258, pl. 42, figs. 1-6; Taylor 1945: 152, fig. 10; Boergesen 1927: 83, fig. 44; Feldmann and Hamel 1934: 112, fig. 19 a-c; Abbott 1947: 203, fig. 5; Fan 1961: 318.

Plants small, clustered, terete, barely $0.5 \mathrm{~cm}$ tall; stoloniferous attachment penetrating the host; branches few, alternate, flattish; tetrasporangia tetrahedral borne terminally.

In effect, our materials show some variations as compared with the descriptions of the same species by different authors. Nevertheless, we prefer to assign this Japanese plant under the above species pending verifications on more materials which may be encountered later.

Materials examined: PAC-JW-1973-109, December 14, 1973. 
Habitat: Epiphytic on matured Gal. subverticillata (PAC-JW-1973-62).

Local distribution: Oguso, Station VI, exposed.

Type locality: England.

\section{Wurdemannia, Harvey}

Wurdemannia miniata (Draparnaud) Feldmann et Hamel.

Abbott 1947: 204, fig. 6; Dawson 1953: 86.

Wurd. setacea in Harvey 1853: 245; Taylor 1928: 145, pl. 20, figs. 19-20.

Thallus to $1.0 \mathrm{~cm}$ in height, attached by numerous disk-shaped holdfasts; firm; sparingly branched, tip of branches acute; cells in surface section ovate to angular.

The present plant is sterile but strongly suggests to be that of the above taxon.

Materials examined: PAC-JW-1973-108, December 14, 1973.

Habitat: Associated with Gel.pusillum, both among the many epiphytes growing luxuriantly on Gal. subverticillata (PAC-JW-1973-62).

Local distribution: Oguso, Station VI, exposed.

Type locality: Mediterranean, France.

Fosliella, Howe

Fosliella farinosa (Lamx.) Howe.

Figs. 26-28.

1920: 587; Dawson 1954: 425, fig. 37 c; Dawson 1956: 49.

Plant forming small, delicate, usually calcareous, circular disks on its hosts; thallus one cell in thickness; heterocysts cells elongated, variable in size, from $20 \mu$ or more long; other cells small, ovate.

This very proliferous crustose alga appears as bright pink 'patches' on the host. The many materials observed, failed to show any fertile individual, suggesting that maturity is not attained in winter!

Its morphological structure, internally, is easily resolved after decalcification with weak solution of $7 \mathrm{~N} \mathrm{HCL}$. As may be noticed, this plant bears numerous smaller epiphytes along its margin.

Materials examined: PAC-JW-1973-88; PAC-JW-1973-89, December 10, 1973; and, PAC-JW-1973-110, December 14, 1973.

Habitat: The first two specimens were found growing on Laurencia (PAC-JW1973-30), the third one on Gal. subverticillata (PAC-JW-1973-62).

Local distribution: Engetsu islet, Station II, exposed (first two); Oguso, Station VI, exposed.

Type locality: Europe.

$$
\text { Jania, Lamouroux }
$$

Key to the Species:

1. Segments mostly to $80 \mu$ in diameter Jan. capillacea 
Segments broader, from 117 to $160 \mu$

2.

2. Plant decussately branched, loose, basally ................................. Jan. decussato-dichotoma

Plant branched but not as above, compressed below Jan. tenella var, tenella

1. Jania capillacea Harvey.

Figs. 24-25.

1853: 84; Dawson 1953: 116, pl. 9, fig. 1; Dawson 1954: 432, fig. 41 a, g; Taylor 1928: 206, pl. 29, figs. 2, 10; Tsuda and Newhouse 1966: 100 .

Plants capillary; branched dichotomously; segments to $80 \mu$ in diameter, cylindric, fine, 4 to 8 diameters long.

The present materials are mostly young (except PAC-JW-1973-101) and therefore sterile. Nevertheless, its vegetative features easily identify itself as one under this species.

Materials examined: PAC-JW-1973-82; PAC-JW-1973-101; and, PACJW-1973-113, December 10, 14, 19, 1973, respectively.

Habitat: Very common calcareous epiphyte growing on several hosts. The first one attached to Laurencia (PAC-JW-1973-30); second, on matured Gal. subverticillata (PAC-JW-1973-62); and, third one making few growths on the stipe of Gal. papillata (PAC-JW-1973-79).

Local distribution: Engetsu islet, Station II, exposed; Oguso, Station VI, exposed; and, Toshima, Station VIII, protected.

Type locality: Florida.

2. Jania decussato-dichotoma (Yendo) Yendo.

1905: 37; Dawson 1953: 117, pl. 27, fig. 3; Dawson 1954: 430, fig. $40 \mathrm{f}$.

Corallina decussato-dichotoma Yendo 1902: 25, pl. 3, figs. 1-3; pl. 7, figs. 3-4.

Plants in small clumps, low, fragile; cylindric branches to $160 \mu$ broad, branching dichotomously at wide angles; sterile.

Our findings agree with those suggested by Yendo $(1902,1905)$.

Materials examined: PAC-JW-1973-103A, December 14, 1973.

Habitat: Epiphytic on Gal. subverticillata (PAG-JW-1973-62).

Local distribution: Oguso, Station VI, exposed.

Type locality: Japan.

3. Jania tenella Kuetzing var. tenella Dawson.

Fig. 29.

1953: 120, pl. 9, fig. 3.

Plants whitish, small, dense, $0.5 \mathrm{~cm}$ tall, fragile, attached by means of small flattish basal disks; branching dichotomously at wide angles below becoming narrower apically; segments cylindric, slightly compressed basally, 117 to $130 \mu$ in diameter, 3-6 times longer than broad; conceptacles wanting.

Though the materials at hand are considerably young, they compare closely with the type characteristics for the variety as repeatedly reported by previous investigators.

Materials examined: PAC-JW-1973-83, December 10, 1973. 
Habitat: Anchored on Laurencia (PAC-JW-1973-30).

Local distribution: Engetsu islet, Station II, exposed.

Type locality: Costa Rica?

\section{Hypnea, Lamouroux}

Hypnea nidulans Setchell.

Tanaka 1941: 246, figs. 18-19.

The specimen is relatively smaller and shows some minor variations from the type, otherwise, agrees with Tanaka's (1941) illustrations based on Japanese materials.

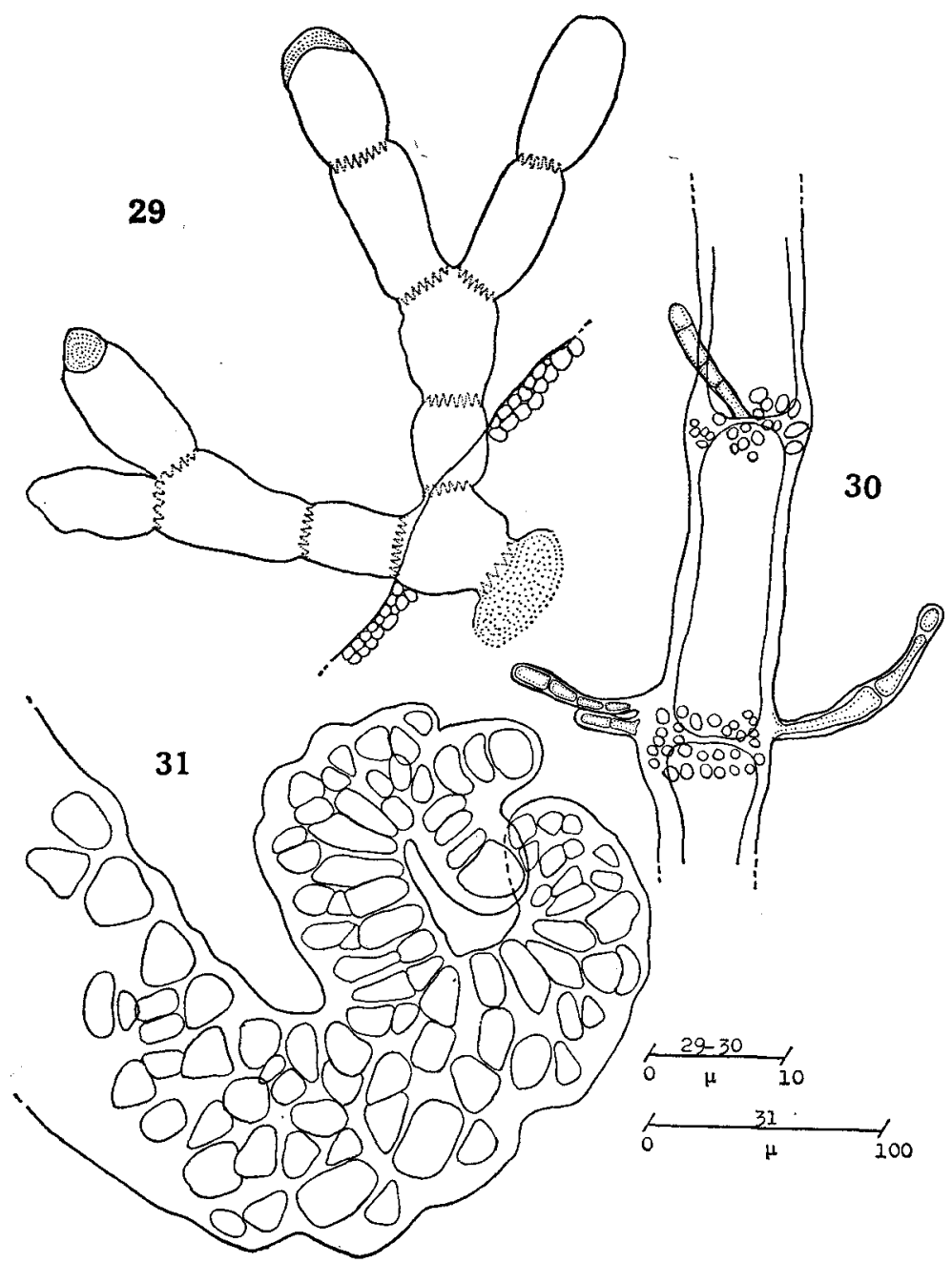

Fig. 29. Jania tenella var. tenella (29) Habit of the plant.

Figs. 30-31. Ceramium mazatlanense (30) Portion of thallus emitting nodal rhizoids.

(31) Tip of matured thallus showing its characteristic in-curved dichotomy. 
Its more prominent short, lateral, sharpish branchlets are found all over the thallus. Reproductive parts not found.

Materials examined: PAC-JW-1973-114, December 12, 1973.

Habitat: Creeping by means of disk-shaped attachment almost penetrating the cortex of its host, Gal. papillata (PAC-JW-1973-79).

Local distribution: Toshima, Station VIII, protected.

Type locality: Samoa.

\section{Centroceras, Kutzing}

Centroceras clavulatum (C. Agardh) Montagne.

Figs. 17-20.

Boergesen 1915-20: 241; Dawson 1944: 321; Dawson 1949: 224; Dawson 1954: 446, fig. h; Dawson 1962: 68, pl. 26, fig. 7; pl. 27, fig. 3; Taylor 1950: 139; Taylor 1960: 537; Abbott 1947: 207; Taylor 1928: 189, pl. 28, figs. 6-7; Reyes 1970: 158.

Plants rather filamentous but usually variable, free floating or may be entangled on other algae; filaments variable in diameter, branching dichotomously; internodes longer basally than above; apices oftentimes forcipate; nodal growths usually 2celled; tetraspore sub-external, arranged in verticils at the nodes, tetrahedral.

This species enjoys a very wide range of distribution in the Pacific waters, generally epiphytic to free floating.

Materials examined: PAC-JW-1973-111, December 14, 1973.

Habitat: On Gal. subverticillata (PAC-JW-1973-62).

Local distribution: Station III, exposed.

Type locality: Peru.

$$
\text { Ceramium, (Roth) Lyngbye }
$$

Ceramium mazatlanense Dawson.

Figs. 30-31 and 36.

1950: 130, figs. 14-15; Dawson 1954: 448, fig. 55 g-j; Dawson 1962: 59, pl. 23, figs. 1-2; Trono 1969: 74, pl. 10, figs. 3, 8; Cornejo, et al 1970: 182, pl. 5, fig. 40; Tanaka and Itono 1972: 11 .

Plants to $6 \mathrm{~cm}$ in height, bright pink when fresh, lying in soft tangled mats among other coarser algae; rhizoidal attachment 1-3 celled, simple, found basally or at nodes; filaments to $75 \mu$ in diameter, usually dichotomously branched, tips prominently curved inward, attenuate. Mature nodes marked by rows of cells to $16 \mu$ in diameter, those below the septum slightly bigger than above, angular; nodal bands close when young, tends to separate towards maturity; central cells 3-4 diameters long, cylindric, reducing in length apically. Tetrasporangia absent.

This plant has a very extensive distribution, though mostly Pacific. A native of Mexico, this has been authoritatively reported from Vietnam (Dawson 1954), Caroline Islands (Trono 1969), and the Philippines (Cordero 1973) as well as Cornejo, et al. (1970).

Materials examined: PAC-JW-1973-100, December 14, 1973. 
Habitat: Plant grows in association with Ulva, Sargassum, and Galaxaura species, although usually epiphytic.

Local distribution: Oguso, Station VI, exposed.

Type locality: Mazatlan, Mexico.

Falkenbergia, Schmitz

?Falkenbergia hildebrandii (Bornet) Falkenberg.

Figs. 32-33.

Dawson 1954: 414, fig. 25, 1.

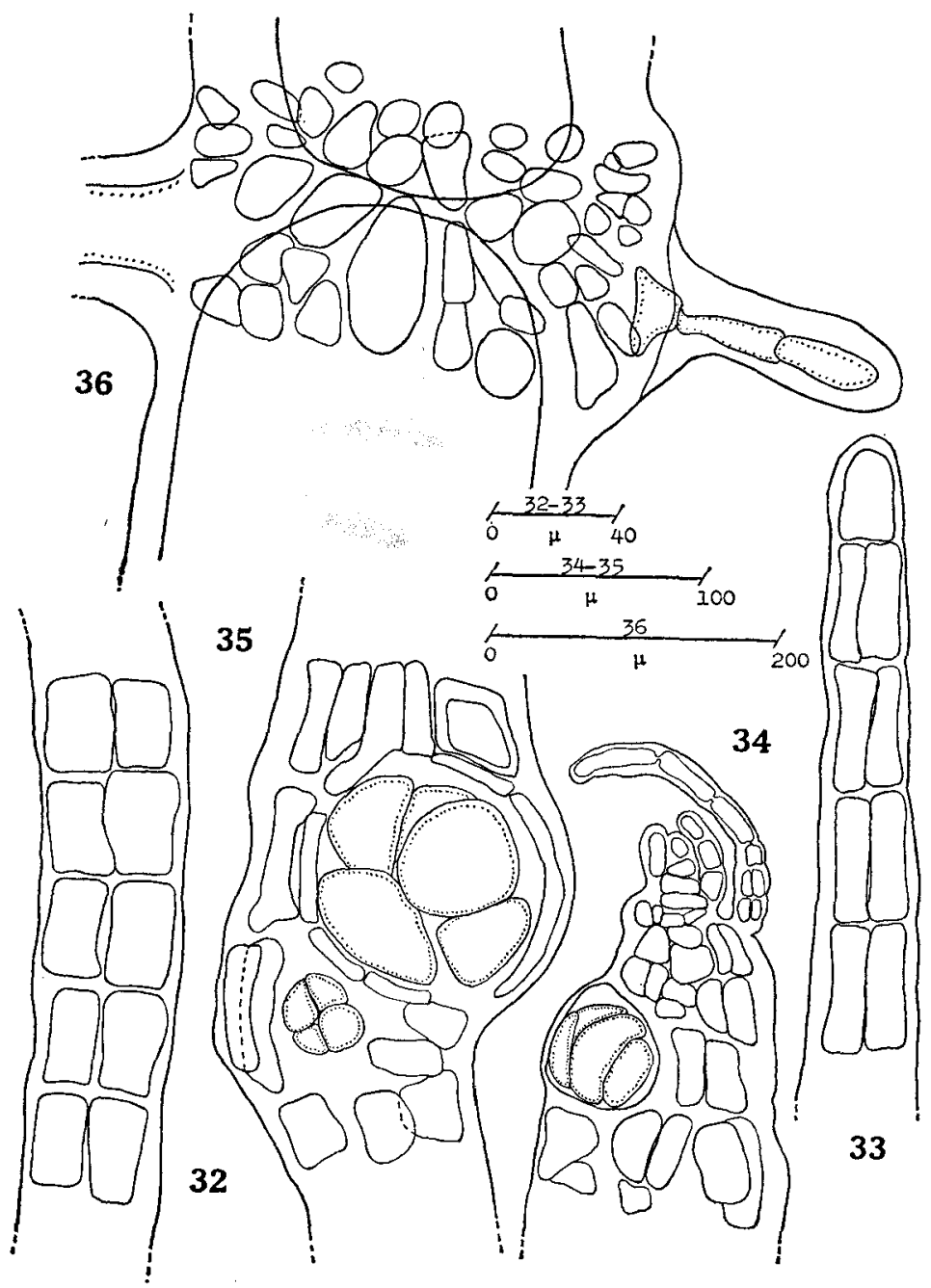

Figs. 32-33. Falkenbergia hildebrandii (32) Mid-frond. (33) Apical portion.

Figs. 34-35. Polysiphonia upolensis (34) Tip of tetrasporic plant. (35) Detailed tetraspores.

Fig. 36. Ceramium mazatlanense (36) Detailed drawing of Fig. 2. 
Plants unbranched, filamentous, 16 to $23 \mu$ in diameter, tip blunt; composed of 2-3 rows of cells in surface section; cells 2 diameters long, filled with cytoplasmic materials; in cross-section 3 pericentral cells are visible.

The materials at hand are sterile, but vegetatively agree with the description made by the above author. However, in the absence of mature and fertile plants as well as more literature about the plant, this writer puts a querie before the scientific name to indicate certain degree of doubt.

Materials examined: PAC-JW-1973-104, December 14, 1973.

Habitat: Always epiphytic; found growing on larger epiphytes like Polysiphonia upolensis (PAC-JW-1973-86), also one of the coarser epiphytes of Gal. subverticillata (PAG-JW-1973-62).

Local distribution: Oguso, Station VI, exposed.

Type locality: Unknown to this writer.

Remark: Falk. hildebrandii has long been confirmed to be the sporophytic phase of Asparagopsis taxiformis, a considerably warm water alga.

\section{Polysiphonia, Greville}

Polysiphonia upolensis (Grunow) Hollenberg.

Figs. 34-35.

1968: 94, figs. 6 D-E, 29, 35, 42.

Thallus low, pseudodichotomous, erect branches of 4 pericentral cells; cells 1.0 to 1.5 diameters long below becoming shorter above; bifurcate, short terminal branchlets incurved, alternate, delicate; trichoblasts to $6.6 \mu$ in diameter or more, polychotomous (1-3) dichotomies, tips arising at intervals, deciduous. Tetrasporangia spirally arranged in the ultimate and sub-ultimate branches; cystocarps globular, to $91 \mu$ in diameter; spermatangial branches shortly stipitate.

One of the more common species of this genus found in the Pacific, it bears identical features with those reported by Hollenberg (1968) from Hawaii and other South Pacific Islands.

Materials examined: PAC-JW-1973-86 and PAC-JW-1973-95, December $10,1973$.

Habitat: Growing on Laurencia (PAC-JW-1973-30) and Gal. fastigiata (PACJW-1973-24).

Local distribution: Both plants came from the same area, Engetsu islet, Station II, exposed.

Type locality: Upol, South Pacific.

Acknowledgments. The writer wishes to thank the Kyoto University for the free use of its laboratory and library facilities at the SMBL; to Dr. Takesi Tanaka, Kagoshima University, for suggestions and comments on the manuscript; to Drs. Takasi Tokioka and Saburo Nishimura, SMBL, Kyoto University, for reading the manuscript and helpful suggestions; to Dr. Shin'ichiro Fuse, also of the SMBL, who kindly provided the chart for Map 2 of this paper; to Mr. Michio Imafuku, doctoral student, 
Kyoto University, a colleague and diving partner; and above all, to the Philippine Government for granting the author an official leave of absence from his regular duties at the National Museum of the Philippines, the second time around.

\section{REFERENCES}

Abbott, I.A. 1947. Brackish-water algae from the Hawaiian Islands. Pac. 1(4): 193-214, 13 pls.

Agardh, J. 1883. Till algaernes systematik. Nya Bidrag. Fjerde Afd. Lunds Univ. Arssk. 23: 1-174, 5 pls.

Boergesen, F. 1913. The marine algae of the Dutch West Indies. I. Ghlorophyceae. Danske Bot. Arkiv. 1(4): 158, 126 figs.

1915-20. Ibid. III. Rhodophyceae. Ibid. 3(1): 1-504, 435 figs.

Buggeln, R.G., and R.T. Tsuda. 1966. A preliminary marine flora from selected habitats on Johnston Atoll. Hawaii Inst. Mar. Biol. Tech. Report No. 9, 29 pp.

Cornejo, D.F., and G.T. Velasquez. 1970. Study on the algal epiphytes of exposed and protected marine waters of Batangas Province. Phil. Jour. Sci. 99(3-4): 165-190, 5 pls. 1 text-fig.

Cordero, P.A., Jr. 1973. The marine algae of Batan Island, Northern Philippines. (M. Sc. Thesis, Kagoshima University, Japan, in press).

- 1974. The marine algae in the vicinity of the Seto Marine Biological Laboratory, with emphasis on Genus Galaxaura: A Preliminary Report. 11 pp., 2 tabs., 6 figs. (type-written),

Dawson, E.Y. 1949. Resultadas preliminaries de un reconocimiento de las algas marinas de las Costas Pacifica de Mexico. Rev. Soc. Mex. Hist. Nat. 9: 215-255.

_- 1953. Marine red algae of Pacific Mexico. I. Bangiales to Corallinaceae. Allan Hancock Pac. Exped. 17(1): 1-171, 33 pls.

- 1954. Marine algae in the vicinity of the Institut Océanographique de Nha Trang, Vietnam. Pac. Sci. 8(4): 373-469, 63 figs.

1956. Some marine algae from the Marshall Islands. Ibid. 10(1): 21-66, 66 figs.

-1962a. Marine red algae of Pacific Mexico. VII. Ceramiales, Delesseriaceae. Allan Hancock Pac. Exped. 26(1): 1-208, 50 pls.

1962b. The seaweeds of Peru. Contrib. Allan Hancock Foundation, Novo Hedwegia, 111 pp. 81 pls.

- 1963. New records of marine algae from the Galapagos Islands. Pac. Nat. 4(1): 1-23, 5 pls.

Egerod, L.E. 1952. An analysis of the Siphonous Chlorophycophyta. Univ. Calif. Publ. Bot. 25(5): $325-454,23$ figs. 14 pls.

Fan, K.C. 1961. Morphological studies of the Gelidiales. Ibid. 32(5) : 315-368, pl. 33-46, 15 text-figs.

Feldmann, J., and G. Hamel. 1934. Observations sur quelques Gelidiacees. Rev. Gen. Bot. 46: 528549.

Harvey, W.H. 1847. Nereis Australis, or Algae of the Southern Ocean. viii +124 pp. 50 pls. London.

-. 1853, 1858. Nereis Borealis Americana...Part II. Rhodospermae and Appendix. 5(5): 1-258, 24 pls.; Part III. Chlorospermae. 5(6) : 1-140, 50 pls.

Itono, H. 1969. The genus Antithamnion (Ceramiaceae) in Southern Japan and adjacent waters - I. Mem. Fac. Fish. Kagoshima University, 18: 29-45, 7 text-figs.

1971. Ibid. - II. Ibid. 20(1): 209-216, 5 text-figs.

1971. The genera Callithamnion, Aglaothamnion, Plenosporium and Mesothamnion (Ceramiaceae, Rhodophyta) in Southern Japan. Ibid. 20(1): 217-237, 12 text-figs.

- 1973. Notes on marine algae from Hateruma Island, Ryukyu. Bot. Mag. Tokyo 86: 155168,35 text-figs.

Hollenberg, G.J. 1968. An account of the species of Polysiphonia of the Central and Western Tropical Pacific Ocean. I. Oligosiphonia. Pac. Sci. 22: 56-98, 43 figs.

Kita, T. and E. Harada. 1962. Studies on the epiphytic communities. I. Abundance and distribution of microalgae and small animals on the Zostera blades. Publ. Seto Mar. Biol. Lab. 10(2): 245-257, 
5 text-figs.

Komai, T., K. Akatsuka, and J. Ikari. 1927. The Seto Marine Biological Laboratory of the Kyoto University. Its equipment and activities, with remarks on the fauna and flora of the environs. Mem. Coll. Sci. Kyoto Univ. Ser. B, 3(3): 281-306, 12 pls. 8 text-figs.

—_, and J. Ikari. 1929. Ibid. (A revised article). Rec. Oceanogr. Works Jap. 1(3): 113-129, pls. 27-35.

Kutzing, F.T. 1849. Species Algarum. Lipsiae.

Menez, E.G. 1964. The taxonomy of Polysiphonia in Hawaii. Pac. Sci. 18(2): 207-222.

Mii, H. 1962. Coastal geology of Tanabe Bay. Sci. Report, Tohoku Univ. 34(1): 1-93, pls 1-6.

Okamura, K. 1907-35. Icones of Japanese Algae. 7 volumes, published by the author, Tokyo. 1934. On Gelidium and Pterocladia of Japan. Jour. Imp. Fish. Inst. 29: 47-67, pls. 16-33. .1934a. Notes on the algae collected near Namariyama, Pref. Wakayama. Jour. Jap. Bot. $10(3): 21-38$.

Reyes, A.Y. 1970. A survey of the littoral benthonic algae of the coastal areas of Dumaguete City. Phil. Jour. Sci. 99(3-4): 131-163, 1 text-fig.

Segawa, S. 1956. Coloured Illustration of the Seaweeds of Japan. 175 pp., Japan.

Setchell, W.A., and N.L. Gardner. 1903. Algae of Northwestern America. Univ. Calif. Publ. Bot. 1: 165-418, pls. 17-27.

Tanaka, T. 1941. Genus Hypnea in Japan. Hokkaido Imp. Univ. Inst. Algol. Res. Sci. Pap. 2(2): 227-250, 2 pls.

1952. The systematic study of Japanese Proto-Florideae. Mem. Fac. Fish. Kagoshima Univ. 2(2): 1-92.

-1956. Marine algae from the Amami Islands and their resources. Mem. South Indust. Sci. Inst. 1: 13-22, pls. 1-2 (in Japanese). 1968. Kaiso-rui no Sei-iku Genkyo to On hai Sui Hoshutsu ni Yoru Eikyo no Yosatsu.

Sendai Genshi Ryoku Hatsudensho Ritsi Joken Chosa Hokoku Sho. pp. 123-129.

Fish. Kagoshima Univ. 2(1): 24-40, 14 figs.

—_ and H. Itono. 1968. Yoron To no Kaiso. Kagoshima Ken Kaichu Koen Gakujutsu Hokoku Sho. pp. 317-325.

—_. and 1969. Sakurajima, Kase, Okikojima, Nagasaki-bana...no Kaiso. Kagoshima Pref. Publ. pp. 83-101.

Fish. Kagoshima Univ., 21(1): 1-14, 5 text-figs.

- 1 , and Balliella, a new genus of Ceramiaceae, Rhodophyta. Bot. Mag. Tokyo 86: 241-252.

Taylor, W.R. 1928. The marine algae of Florida with special reference to the Dry Tortugas. Carnegie Inst. Wash. Publ. 25: 1-219, 37 pls.

- 1950 . Plants of Bikini. xv $+226 \mathrm{pp}, 79 \mathrm{pls}$. Univ. Mich. Press, Ann Arbor, Michigan.
- The Marine Algae of the Eastern Tropical and Subtropical Coasts of the Americas. $662 \mathrm{pp} .$, 80 pls.

Trono. G.C., Jr. 1968. The marine benthic algae of the Caroline Islands. I. Introduction, Chlorophyta and Cyanophyta. Micronesica 4(2): 137-206.

- 1969. Ibid. II. Phacophyta and Rhodophyta. Ibid. 5(1): 25-119.

Tsuda, R.T., and J. Newhouse. 1966. Marine benthic algae from Addu Atoll, Maldive Islands. Atoll Res. Bull. No. 116, 93-102 pp.

Umezaki, I. 1952. Some marine Cyanophyceae from Shirahama Coast of Wakayama Prefecture. Publ. Seto Mar. Biol. Lab. 2: 235-248.

1967. On a microscopic phase in the life cycle of Nemalion pulvinatum Grunow (Nemalionaceae, Rhodophyta). Ibid. 15(4): 311-318, pls. 6-10.

- 1968. A study on the germination of carpospores of Dudresnaya japonica Okamura (Rhodophyta). Ibid. 16(4): 263-272, pls. 19-20, 5 text-figs.

1971. The tetrasporophyte of Scinaia japonica Setchell (Nemalionales - Rhodophyta). Ibid. 
19(2-3): 65-71, pls. 2-3, 25 text-figs.

Weber van Bosse, A. 1913-28. Liste des algues du Siboga. Siboga Expeditie Monograph 59: 1-533, 16 pls. E.J. Brill. Leiden.

110,16 pls.

Yamada, Y., and T. Tanaka. 1938. The marine algae from the island of Yonakuni. Sci. Pap. Inst. Algol. Res. Hokkaido Imp. Univ. 2(1): 53-86.

Yendo, K. 1902. Corallinaceae verae Japonicae. Tokyo Imp. Univ. coll Sci. 16(2): 1-36, 7 pls. - 1905. A revised list of Japanese Corallinaceae. Ibid. 20(12): 1-46.

Yoshida, K. 1970. Studies on germling development and life history in Ulvaceae and Monostromaceae. Part I. Publ. Seto Mar. Biol. Lab. 17(6) : 403-428, 9 text-figs.

1970. Ibid. Part II. 18(4): 243-273, 22 text-figs. 